Jarmo Saarti, Liisa Savolainen, Mira Juppi, Hanna Lahtinen, Miia Willman, Heli Kautonen ja Kimmo Tuominen

\title{
TIETEELLISET KIRJASTOT VUONNA 2030 - KATSAUS KESKEISEEN STRATEGIATYÖHÖN
}

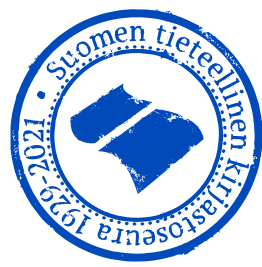

\section{Strategiaa voi tarkastella erilaisilla aikajänteillä ja erilaisista} näkökulmista, strategiapaperia voi työstää ja toteuttaa monella tavalla. Tässä artikkelissa luodaan silmäys eri sektoreilla tehtävän strategiatyön viimeisimpiin viilauksiin - fokus on erityisesti 2020-luvun kehityksessä. Artikkelissa tieteellisen kirjastomaailman eri toimijat käsittelevät strategiaa omista lähtökohdistaan. Painotukset vaihtelevat, mutta toimintaympäristön analyysissä on myös yhteisiä piirteitä.

Vuonna 2020 tehtiin kirjastosektoreilla paljon strategiatyötä. Korkeakoulut päivittivät omia strategioitaan osana tulossopimuksia seuraavalle kolmivuotiskaudelle. Myös kansallisten palveluiden strategioita uudistettiin. Korona antoi oman lisänsä tälle keskustelulle: erityisesti tieteen ja tutkimuksen digitaaliset palvelut ja etätyön lisääntyminen näyttävät vaativan oman päivityksensä jo lähitulevaisuudessa.

Strategiamaalit 2024, 2030 ja 2050 - haasteet ja visiot Jarmo Saarti

$A_{\text {teiden asettelua ovat määritelleet }}^{\text {lkavaa strategiakautta ja tavoit- }}$ lyhyen ja pitkän tähtäyksen tavoitteet. Lyhyen tuloskauden 202 I-2024 tavoitteet korkeakoulujen opetukselle ja tutkimukselle ovat periaatteessa selkeitä: opetukseen ja tutkimukseen ollaan Suomessa valmiita satsaamaan, erityisesti jatkuvaan oppimiseen ja tutkimuksen korkean tason varmistamiseen. Koronatilanne tuo tähän kuitenkin oman mausteensa: Emme vielä tiedä, miten Suomen ja Euroopan kansantaloudet selviävät pandemiasta, joten sekä leikkaukset että satsaukset ovat mahdollisia.

Vuoteen 2030 tähtäävä puhe Suomessa liittyy selkeästi osaamisen uudistamiseen ja toisaalta väestöpolitiikan haasteisiin. Kansallisesti halutaan varmistaa suomalaisten osaamisen korkea taso ja samalla menestyä kansainvälisessä kilpailussa osaavasta työvoimasta. Kansainvälisellä tasolla vuosi 2030 on asetettu YK:n kestävän kehityksen ohjelman tavoiteaikatauluksi, ja Suomessa kaikki hallinnonalat ovat sitoutuneet siinä esitettyihin kestävän kehityksen tavoitteisiin. Kestävä kehitys on selvästi kattava strateginen tavoite tällä hetkellä. Vuoteen 2030 mennessä EU:n ja Suomen tavoite on edetä nopeasti kohti täysin avointa tiedettä, joka on merkittävä korkeakoulukirjastojen palveluita määrittävä tekijä alkavalla strategiakaudella.

Vuoteen 2050 suuntautuvat näkymät muuttuvat sumeammiksi ja samalla haastavammiksi. Tällä aikajanalla 
aletaan puhua Suomessa väestön ikääntymisen ja alenevan syntyvyyden vaikutuksista. Jos syntyvyyden lasku jatkuu, seurauksena on koulutusrakenteiden saneeraus, joka on aloitettava jo tällä vuosikymmenellä.

Kansalliskirjasto panostaa tiedon saatavuuteen Liisa Savolainen

T ämän päivän opiskelijat valmistuvat 4-6 vuoden päästä ja ovat yhteiskunnan muutosagentteja ehkä kymmenen vuoden päästä. Uusimmat opetus- ja kulttuurialan strategiat on luotu kymmenen vuoden aikajänteelle, näin esimerkiksi opetus- ja kulttuuriministeriön strategia sekä Helsingin yliopiston strategia. Mutta miten kymmenen vuoden strategia sopii kirjastoille? Kirjastot ovat toimintaympäristönsä mukaan muuttuvia palveluorganisaatioita ja riippuvaisia teknologisesta kehityksestä. Löytyykö sellaisia tulevaisuuden ennustajia, jotka näkevät palvelutuotannon kehittämistarpeet seuraavaksi kymmeneksi vuodeksi? Jos katsomme mennyttä kymmentä vuotta, on toimintaympäristömme muuttunut tavalla, jota harva osasi ennustaa.

Kymmenen vuoden strategia edellyttää pitkien trendien tunnistamista. Sitran Megatrendit 2020 -julkaisu määrittelee megatrendin useasta ilmiöstä koostuvaksi kehityssuunnaksi, laajaksi muutoksen kaareksi. Yksittäistä megatrendiä olennaisempaa on ymmärtää, mihin laajempaan kokonaisuuteen se liittyy. Lisäksi viime vuosina on alettu puhua tulevaisuuskyvykkyydestä. Käsite tarkoittaa niin yksilön kuin yhteis- kunnan kykyä kuvitella vaihtoehtoisia tulevaisuuksia mutta myös toimia halutun tulevaisuuden eteen. Megatrendien taustalta voi vielä tunnistaa metatrendejä, eli eri teemoja poikkileikkaavia ja kehityskulkujen muutokseen vaikuttavia asioita.

Kirjastojen osalta on helppo hahmottaa hallitsevia megatrendejä: jatkuva teknologinen kehitys, informaation määrä kasvu ja informaation tuottajien sekä informaation sisällön lisääntyvä heterogeenisyys. Suomessa kulttuurinen monimuotoisuus kasvaa ja väestö ikääntyy. Toisaalta verkkoympäristö vahvistaa samankaltaisten ja -mielisten kuplia, jolloin monimuotoisuus voi myös heijastua yhteiskunnan sisäisenä polarisaationa.

Näistä trendeistä voitaneen suoraan johtaa haasteita kirjastotoimintaan. Miten varmistaa luotettavan tiedon saatavuus ja kirjastojen asema sen välittäjinä? Entä miten kirjastot palveluorganisaatioina varmistavat teknologisen ajantasaisuutensa? Tulevaisuudessakin kirjastopalvelujen on oltava digitaalisesti helposti saavutettavia ja käyttöominaisuuksiltaan kilpailukykyisiä.

\section{Kansalliskirjaston valinnat}

Kansalliskirjasto valitsi strategiatyössään neljä ohjaavaa tavoitetta: I) Kulttuuriperintö yhteiseksi hyväksi, 2) Kansalliskirjasto tiedeyhteisön ytimessä, 3) Kansalliskirjasto sivistyksen ja oppimisen voimavarana ja 4) Verkostoyhteistyön kautta vahvaksi osaamiskeskukseksi.

Strategiset tavoitteet korostavat kirjaston ydinpalvelua eli kulttuuripe- 


\section{8}

rinnön tallettamista ja saatavuuden edistämistä sekä tiedeyhteisön palvelemista, mutta myös kirjaston roolia muistiorganisaatioiden verkostokumppanina. Keskeiset keinot tavoitteiden saavuttamiseksi ovat teknologian ja julkaisutuotannon myötä kehittyminen sekä vahva verkostoituminen erilaisten asiantuntijaorganisaatioiden kanssa. Kansalliskirjasto kehittyy ja kehittää palveluitaan yhteistyössä sekä kansallisten että kansainvälisten kumppanien kanssa.

\section{Ikuinen missio ja päivittäiset palvelut}

Kansalliskirjasto on palveluorganisaatio ja sen olemassaolon oikeutuksena on tuottaa lisäarvoa asiakkaille. Kuitenkin kansallisena muistiorganisaationa kirjaston missio on paljon kauaskantoisemmissa periaatteissa. Kansalliskirjaston toimii sivistyksen perustana, mahdollistaa suomalaisen kulttuurin ja yhteiskunnan tutkimuksen sekä varmistaa julkaistujen lähdeaineistojen säilyvyyden. Sivistyksen kivijalkana ja tutkimuksen tukena Kansalliskirjasto vahvistaa tutkitun tiedon saatavuutta, tätä kautta demokratiaa ja tasavertaisuutta sekä antaa kehityksen ja opin mahdollisuuksia koko kansakunnalle.

\section{Dataosaaminen keskiöön}

Digitaalisten alustojen jatkuva uusiutuminen ja julkaisutuotannon muuttuminen tarkoittaa Kansalliskirjastolle osaamis- ja teknologiahaastetta. Kirjasto on strategiassaan asettanut tavoitteen olla maailman huippuluokkaa sähkösyntyisten aineistojen tallettajana. Ta- voite tarkoittaa käytännössä sitä, että Kansalliskirjaston tulee varmistaa korkeatasoinen IT-osaaminen pysyäkseen dynaamisesti muuttuvan verkkoviestinnän ja uusien julkaisuformaattien kehityksessä mukana. Uusi tehtäväalue on verkkomaailman aktiivinen seuranta: millaisilla alustoilla julkaistaan ja missä käydään ajankohtaisia keskusteluja. Onhan Kansalliskirjaston perimmäisenä tehtävänä ajankuvan tallettaminen tuleville sukupolville. Osaamisen - erityisesti strategisen huippuosaamisen - tunnistaminen, sen ylläpito ja turvaaminen ovat perusta kirjaston tehtävien toteutumiselle myös tulevaisuudessa.

Aineistojen saatavuuspalveluna Finna pyrkii parhaaseen mahdolliseen käyttäjäkokemukseen eli tuomaan tieteen ja kulttuurin aineistot kilpailukykyisesti esille. Finnan palvelukehittäminen pyrkii vastaamaan teknologian ja oppimisen muutoksiin. Tärkeänä toimintatapana on verkostoituminen yhteiskehittämisessä: Kotimaiset muistiorganisaatiot eivät ole vain Finnan asiakkaita, vaan kehittämistyön kumppaneita, monesti myös uusien avausten promoajia.

Finnan uudet avaukset strategiakaudella liittyvät oppimateriaalien tarjontaan ja tutkimuksen uusiin palveluihin. Finna-tutkijasali on kehittämishanke, jonka tavoitteena on saada tutkijoiden käyttöön näyttö- ja käyttörajoitetut aineistot. Nämä ovat lähinnä rajoitetussa käytössä olevia arkistoaineistoja ja ensimmäisessä vaiheessa Finna-tutkijasalin on tarkoitus mahdollistaa aineistojen metatietojen 
saatavuus.

Ihmistieteiden tutkimuksessa käytetään yhä laajemmin dataa lähdeaineistona. Kirjaston palvelimille dataa syntyy sekä historiallisten aineistojen digitoinnista että ajantasaisen digitaalisen informaatiovirran tallettamisesta. Kirjaston digitaalisia aineistoja on lähinnä kahdessa palvelussa - digi. kansalliskirjasto.fi -palvelussa ja Verkkoarkistossa. Verkkoarkistoon on tallennettu Kansalliskirjaston tallentamat kotimaiset verkkosivut ja muut verkkoaineisto - vaikkapa vuodesta 2020 lähtien kirjaston tallentamat Twitter-tilit. Varsinaiset elektroniset julkaisut ovat Varia-tietokannassa. Sekä Verkkoarkisto että Varia-tietokanta ovat paikallisesti käytettävissä vapaakappalekirjastoissa.

Erityisesti tutkimuksen tarpeista katsoen yksi tulevaisuuden tärkeimpiä kysymyksiä on se, miten tätä tallennettua sähkösyntyistä kulttuuriperintöä saadaan dataintensiivisen tutkimuksen käyttöön. Nykyinen lainsäädäntö ei mahdollista tiedonlouhintaa näitä aineistoista, ja saattaa hyvinkin olla, ettei myöskään uusi tekijänoikeuslaki tätä mahdollista. On kuitenkin tärkeää, että jatkossa löydetään jokin tapa asettaa sähkösyntyinen kulttuuriperintö tutkimuskäyttöön. Digitoitujen aineistojen osalta kirjasto pystyy sopimusteitse mahdollistamaan laajaa tutkimuskäyttöä.

Dataintensiivisessä tutkimuksessa korostuu kirjastojen - tai tutkimusinfrastruktuurien - kehittäjäkumppanuus tutkijoiden kanssa. Datapalvelut edellyttävät kirjastolta suurempaa datan- hallinnan kyvykkyyttä ja yhteistyötä tiedeyhteisön sekä muiden dataintensiivisten palveluiden kanssa. Teknologisen ja sisältöosaamisen ohella tässäkin korostuu kyky verkostoitumiseen - yhdessä olemme enemmän.

\section{Avoimuus johtotähtenä}

Kansalliskirjaston tavoitteena on tieteellisten julkaisujen parempi saatavuus, yleisen tietotason nousu sekä opetuksen ja tutkimuksen tehostuminen. Kansalliskirjasto on jo useamman vuoden tukenut avointa julkaisemista. Vaikuttavin tapa tähän ovat ns. transformatiiviset sopimukset. Transformatiivisilla sopimuksilla siirretään aiemmin lehtitilauksiin käytettyä rahaa avoimeen julkaisemiseen ja tavoitteena on, että jatkossa kustantaja muuttaa neuvoteltujen lehtipakettien lehdet avoimiksi lehdiksi. Vuonna 2020 suomalaiset tutkijat julkaisivat avoimena FinELib-konsortion käymien neuvottelujen tuloksena lähes 3000 artikkelia ja vuodelle 202 I tavoitteena on 4500 avointa artikkelijulkaisua.

Julkaisuarkistopalvelu tarjoaa avoimen julkaisukanavan lähes 50 kotimaiselle organisaatiolle. Nämä avoimet julkaisut, joista monet ovat opinnäytteitä, siirtyvät julkaisuarkistosta pitkäaikaissäilytykseen muun julkaisutuotannon ohessa. Myös omassa kokoelmanmuodostuksessaan Kansalliskirjasto siirtyy vähitellen suosimaan avoimia julkaisuja - tosin tie on pitkä. Avointen julkaisujen suosiminen muuttaa kirjaston perinteistä aineistojen käyttöönasettamista ja kokoelmahallintaa. Avoimuus on tärkeää tiedon 
tasavertaisen saatavuuden kannalta; tämä on arvo johon Kansalliskirjasto on sitoutunut.

AMKIT-konsortion strategia 2021-2025: käytännöstä strategiaksi

Mira Juppi, Hanna Lahtinen ja Miia Willman

\section{A} MKIT-konsortio on suomalaisten ammattikorkeakoulukirjastojen yhteistyökonsortio. Konsortion strategia laaditaan viideksi vuodeksi kerrallaan: Viidessä vuodessa ympäristön muuttujat ovat vielä melko hyvin ennustettavia ja strategia voidaan pitää käytännön läheisenä ja toimintaa aidosti ohjaavana työkaluna. Strategiakaudella 202 I-2025 konsortion keskeisiä teemoja ovat avoimuus, oppiminen, vaikuttavuus ja yhteistyö.

Strategian ainekset tulevat konsortion sisältä ja sen ulkopuolelta. Keskeisistä teemoista avoimuus ja vaikuttavuus sisältävät suuria kansallisia toimenpiteitä, kuten kansalliset avoimuuden linjaukset, kestävän kehityksen ohjelman ja digivision. Konsortio edistää jäsentensä mahdollisuuksia vastata teemojen tuomiin haasteisiin ja vaikuttaa mahdollisuuksien mukaan kansallisesti jäsentensä toimintaa koskeviin asioihin.

Yhteistyö on konsortion toiminnan ydin; panostamme niin konsortion sisäiseen kuin ulkoiseen yhteistyöhön. Kehitämme yhteistyön muotoja ja yhdessä oppimisen kulttuuria. Vahvistamme jäsenten asiantuntemusta ja mahdollistamme uusien yhteistyöverkostojen muodostumisen ja hyödyntä- misen. Haemme ennakkoluulottomasti uusia kumppaneita perinteisiä rajoja ylittäen.

Konsortion jäseniä kannustetaan yhteiseen keskusteluun ja avoimen toimintakulttuurin ylläpitämiseen. Yhteistyömme tavoitteena on ajatusten vaihto ja uuden oppiminen. Näkemysten monipuolisuus on arvokasta yhteisessä kehittämisessä ja kollegiaalinen tuki on tärkeää. Emme halua tehdä asioita liian ryppyotsaisesti: pyrimme luomaan iloa ja keveyttä yhdessä tekemiseen ja yhteisten haasteiden ratkaisemiseen. Strategiamme heijastelee tahtotilaamme ja visiomme onkin Mahdollistava konsortio - avoimesti ja iloisesti yhdessä!

\section{Käytännöstä strategiaksi}

Strategia valmistellaan yleensä johdon kesken ja tuodaan valmiina työntekijälle toimeenpantavaksi. Tämä toimintatapa johtaa kuitenkin usein siihen, että jalkauttaminen ei onnistu, koska strategia ei ole yhteisen pohdinnan ja tahdon tulos.

AMKIT-konsortion strategiaa lähdettiin pohtimaan alhaalta ylöspäin eli työntekijän näkökulmasta, tavoitteena työstää se yhdessä käytännöstä strategiaksi. Lähetimme amk-kirjastojen työntekijöille kyselyn, jossa tiedustelimme, minkälaista yhteistyötä kollegoiden kanssa toivotaan ja mitä asioita tai teemoja konsortion yhteistyöstrategiassa tulisi olla. Vapaamman keskustelun avaamiseksi lähetimme amk-kirjastolaisille linkin Jamboard-keskustelualustalle, jossa sai tuoda mielipiteensä esiin strategian teemoi- 
hin liittyen.

Kyselyn ja keskustelualustan pohjalta laadimme koonnin, jota käsiteltiin kirjastonjohtajien pienryhmissä ja AMKIT-konsortion vuosikokouksessa syksyllä 2020. Vuoden lopulla järjestimme vielä kaikille avoimen webinaarin, jossa jatkoimme strategian työstämistä yhdessä. Webinaari tallennettiin, jotta mahdollisimman moni pystyisi osallistua strategian valmisteluun ja kommentteja toivottiin lähetettävän myös jälkikäteen. Keskusteluissa nousi esiin, että yhteistyön konsortiossa toivottiin olevan helppoa ja luonteva osa arkea. Pidettiin myös tärkeänä, että opimme toisiltamme, mutta myös kumppaneilta ja sidosryhmiltä. Toivottiin, että AMK-kirjastojen vaikuttavuus korkeakouluissa nostettaisiin paremmin esiin.

Työntekijöiden esiin nostamia asioita peilattiin konsortion ulkopuolella tapahtuvaan kehitykseen ja pyrittiin löytämään ne asiat, joilla on kirjastoille suuri merkitys ja joihin konsortio voi vaikuttaa. Strategiaa muokattiin saatujen kommenttien perusteella ja luonnosta työstettiin vielä yhteisesti AMKIT-verkostopäivässä helmikuussa 202 I (ks. AMKIT-konsortio 202 I). Lopullinen versio strategiasta hyväksytään AMKIT-konsortion huhtikuun vuosikokouksessa.
Erikoiskirjastojen ja tietopalveluiden strategia keskittyy perusasioihin Heli Kautonen

orkeatasoista tutkimusta tehdään I myös yliopistojen ulkopuolella. Erikoiskirjastot ja tietopalveluyksiköt palvellakseen juuri tätä tutkijakuntaa - toki myös akateemisia tutkijoita ja kansalaisia. Osa Suomen erikoiskirjastoista toimii tieteellisissä seuroissa, osa valtionhallinnon tutkijakunnan lähettyvillä, osa laitoksissa, joiden yhteys tieteelliseen tutkimukseen näkyy ovesta sisään astuttaessa, verkkopalveluita käytettäessä tai tietopalvelua kysyttäessä.

Poikkeuksellinen vuosi 2020 toi myös erikoiskirjastoihin kiirettä ja osoitti, ettei yhteiskuntamme toimisi yhtä tehokkaasti ilman kirjastojen valmiutta tarjota luotettavaa tutkimustietoa nopeasti saataville. Erikoiskirjastojen ja tietopalveluiden strategia heijasteleekin koronavuoden ilmapiiriä, keskittymistä kaikkein olennaisimpiin perusasioihin. Samaan aikaan kun erikoiskirjastojen neuvosto työsti uutta strategiaa tuleville vuosille, koronapandemiaa ja sen vaikutuksia selvittelevät tutkijat kaipasivat syvällistä ja ajankohtaista tilastotietoa, tietoa lainsäädännöstä, kriisin vaikutuksista erilaisten kansalaisryhmien arkeen, kansakuntamme kokemista aiemmista pandemioista ja selviytymiskeinoista - tai virkistävää vaihtelua etätyöarkeensa.

Koska erikoiskirjastojen verkosto koostuu hyvin erilaisista toimijoista, yksi strategiakausia ylittävistä kehit- 
Erikoiskirjastojen ja tietopalveluiden verkoston strategiset tehtävät vuosina 2021-2025:

- Hyödynnämme, kehitämme ja vahvistamme koko verkoston osaamista.

- Tuomme erikoiskirjastot ja tietopalvelut näkyväksi ja vaikuttavaksi osaksi kirjastoverkkoa.

- Jaamme erikoiskirjastojen ja tietopalvelujen syvää osaamista kaikkien saataville. tämiskohteista on verkoston jäseniä yhdistävän identiteetin rakentaminen. Toisin kuin muilla kirjastosektoreilla, erikoiskirjastojen taustaorganisaatioiden tehtävät ja toimintaa ohjaavat normit eroavat suuresti. Verkoston jäsenet pyörittävät palvelujaan myös hyvin erilaisin voimavaroin. On haastavaa kertoa kysyjälle, mikä erikoiskirjastoja yhdistää, kun silmiinpistävin yhteinen tekijä tuntuu olevan erilaisuus.

Toisaalta erikoiskirjastojen ja tietopalveluyksiköiden heterogeenisyydessä voi oivaltaa monimuo-

tuneiden kirjastopalveluiden toimintaedellytyksiä liiaksi leikataan. Tässä auttanevat vaikkapa pandemiavuonna kasvaneet e-aineistojen käyttötilastot tai noutopalvelumahdollisuutta kiittävien tutkijoiden lausunnot.

Kolmas erikoiskirjastojen ja tietopalveluiden uuteen strategiaan kirjattu kehittämiskohde on entuudestaan tuttu: Kirjastojen välinen yhteistyö on perusasia, joka voi vain parantua uudesta energiasta ja ideoista. Vastikään Kansalliskirjaston järjestämässä pyöreän pöydän tilaisuudessa totesimme, että mitä enemmän samoja kysymyksiä pohtivat ihmiset jakavat tietoa keskenään, sitä tehokkaampaa ja laadukkaampaa palvelua kaikki saavat. Samalla tuli todetuksi, että maailman muuttuessa verkostomme erikoisasiantuntijat voivat olla tärkeitä yhteistyökumppaneita myös muille kirjastoille, koko kirjastokentälle.

Yliopistokirjastot rakentavat tulevaisuutta verkostojen kautta Kimmo Tuominen

käyttäjäryhmille. Tämä onkin yhteisen identiteettimme perusta.

Erikoiskirjastojen verkostossa on jo nähty ja koettu, miten tiukat taloudelliset ajat karsivat rivejämme. Olemme kehittäneet joustavuutta sekä jatkaneet kirjasto- ja tietopalveluita supistetuin kokoelmin, karsituin toiminnoin tai sulautettuna osaksi muuta organisaatiota. Kireä talous jatkunee ja siksi yhtenä strategisena painopisteenä on vaikuttavuuden osoittaminen. Meidän pitää verkostona tehdä näkyväksi se, miten korvaamattomia tiedonlähteitä yhteiskuntamme menettää, jos erikois-
Y

liopistojen tehtävänä on edistää vapaata tutkimusta sekä tieteellistä ja taiteellista sivistystä, antaa tutkimukseen perustuvaa ylintä opetusta sekä kasvattaa opiskelijoita palvelemaan isänmaata ja ihmiskuntaa. Suomessa tätä yliopistolain juhlallisesti määrittelemää tavoitteenasettelua toteuttaa I 3 yliopistoa, joista kaksi on julkisoikeudellista säätiöitä ja loput julkisoikeudellisia laitoksia. Sotilasalan korkeakoulutuksesta ja tutkimuksesta vastaa Suomen puolustusvoimiin kuuluva Maanpuolustuskorkeakoulu. 
Yliopistoilla on autonomia, ja niitä koskee tieteen ja tutkimuksen vapaus. OKM ohjaa, valvoo ja rahoittaa yliopistojen toimintaa. Se käy sopimusneuvottelut yliopistojen kanssa, jakaa niiden käytettävissä olevan perusrahoituksen määrittelemänsä rahoitusmallin mukaisesti ja osoittaa lisäksi yliopistoille strategista rahoitusta.

Myös muilla tieteen rahoittajilla, kuten OKM:n alaisena virastona toimivalla Suomen Akatemialla, on mahdollisuus vaikuttaa yliopistojen toimintaan. Esimerkiksi Suomen Akatemian liittyminen tutkimusrahoittajien Coalition S:ään on vaikuttanut vahvasti niin kansallisiin avoimen tieteen linjauksiin kuin FinELib-konsortion tavoitteisiinkin.

Kansallinen tiedepolitiikka on edistänyt korkeakoulujen ja korkeakoulutuksen keskittämistä, mutta toisaalta viime aikoina on väläytelty jopa uuden yliopiston perustamista. Yliopistojen kehittämiseen liittyy ja on aina liittynyt myös aluepoliittisia päämääriä. Tiede- ja aluepoliittiset tavoitteet voivat muuttua esimerkiksi hallitusvallassa olevien poliittisten puolueiden vaihtumisen vuoksi.

Yliopistokirjastot eivät ole erillisiä saaria, vaan ne toimivat osana yliopistoaan ja korkeakoulukenttää ja ovat usein myös emo-organisaatioidensa näköisiä toimijoita. Tiedepolitiikan sekä toiminnan taloudellisten ja juridisten reunaehtojen muutokset heijastuvat myös yliopistojen kirjastoihin, jotka ovat monasti etunenässä toteuttamassa esimerkiksi yliopistojensa integroitumissuunnitelmia. Viime vuosina yliopistokirjastot ovat joutuneet tottumaan nopeisiin toimintaympäristön muutoksiin, jotka ovat vaikuttaneet myös kirjastojen palveluihin. Toimintaresurssien niukkeneminenkin on ollut yleisempää kuin niiden kasvu.

Yliopistokirjastot eivät tietenkään vain reagoi ympäristöönsä, vaan ne ovat mukana luomassa omaa tulevaisuuttaan sekä vaikuttamassa tutkimustoiminnan ja opiskelun tuloksellisuuteen. Parhaimmillaan yliopistokirjastot voivat toimia oman organisaationsa muutoksen vetureina esimerkiksi avoimen tieteen edellyttämien paradigmamuutosten toteuttamisessa.

Pienessä maassa yliopistokirjastojen on ollut tarkoituksenmukaista yhdistää resursseja ja tehdä yhteistyötä, vaikka opetus- ja kulttuuriministeriön rahoitusmalli ja esimerkiksi erilaiset yliopistorankkaukset rakentavatkin samanaikaisesti kilpailuasetelmaa yliopistojen välille. Kirjastot ovat aina olleet hyviä tekemään yhteistyötä keskenään, niin kansallisesti kuin kansainvälisestikin.

Kirjastoammatillisilla verkostoilla on ja tulee olemaan tärkeä rooli luotaessa uusia palveluja ja yhteisiä strategisia avauksia. Yliopistokirjastojen keskinäinen yhteistyö on edesauttanut esimerkiksi informaatiolukutaito-, metriikka- ja tutkimusdatapalveluiden luomista ja muotoilua. Kansallinen kirjastoalan yhteistyö saa tulevaisuudessa uusia muotoja ja vanhat toimintarakenteet saattavat menettää merkitystään. Vaikka yhteistyön tavat ja muodot muuttuvat, tietyt säännönmukaisuudet säilyvät: mistään ei tule

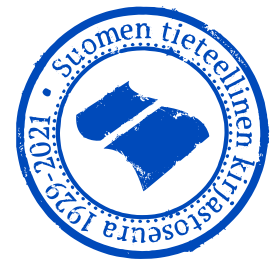


mitään, jos toimijat eivät esimerkiksi luota toisiinsa. Raskaat yhteistyörakenteet, kuten konsortiot, voivat ajan myötä muuttua myös dysfunktionaalisiksi, jolloin ne jarruttavat pikemminkin kuin jouduttavat kehitystä. Koska yliopistokirjastojen palvelutoiminta joka tapauksessa muuttuu ja digitalisoituu, myös yhteistoiminnan rakenteiden on syytä seurata kehitystä.

\section{Moniammatillinen yhteistyö}

Viime vuosina yliopistokirjastot ovat entistä paremmin integroituneet emo-organisaatioihinsa ja ryhtyneet tekemään moniammatillista yhteistyötä yliopistojen sisällä esimerkiksi yhden luukun periaatteella toteutettavien tutkijoiden ja opiskelijoiden palveluiden tuottamisessa. Tämä kehitys jatkuu vastaisuudessakin: mielenkiintoisimmat innovaatiot toteutuvat usein juuri eri alojen ja toimijoiden rajapinnoilla.

Moniammatillisen yhteistyön seurauksena tiedeyhteisön jäsenten kyky hahmottaa kirjastojen ja kirjastolaisten potentiaalia on viime aikoina parantunut. Yliopistokirjastojen tulee silti vastaisuudessakin kyetä osoittamaan toimintansa vaikuttavuus niin yliopistojen johdolle kuin sidosryhmille ja asiakkaillekin.

Eurooppalaiset yliopistoallianssit ja muut yliopistojen keskinäiset kansainväliset verkostot tulevat kasvattamaan rooliaan myös yliopistokirjastojen kehittämisessä. Nämä allianssit ja verkostot nousevat kirjastoalan perinteisemmän kansainvälisen yhteistyön rinnalle, ja ne tulevat vaikuttamaan kirjastojen ja niiden emo-organisaatioiden strategisiin valintoihin. Tutkimuksessa ja opetuksessa rakennetaan yhä kansainvälisempiä infrastruktuureja ja kansainvälinen yhteistyö tulee saamaan, myös yliopistokirjastojen osalta, totuttua syvemmälle meneviä muotoja.

Uudet innovaatiot ja strategiset avaukset edellyttävät ennakkoluulottomuutta ja yliopistokirjastojen traditionaalisen roolin laajentamista. Resurssitilanteen heikentyminen voi johtaa myös haastaviin päätöksiin: mistä voidaan luopua ja mitä voidaan tehdä vähemmän? Paras lopputulos saadaan, kun yliopistokirjastojen henkilökunta pääsee osallistumaan strategiatyöskentelyyn ja sitä seuraavaan toimintaprosessien uudistamistyöhön. Osallistava strategiatyö varmistaa myös sen, että kaikki kirjastolaiset työskentelevät yhdessä valittujen tavoitteiden toteuttamiseksi.

Yliopistokirjastoilla on halutessaan potentiaalia olla ennakkoluulottomia uuden tekijöitä. Vaihtoehtoisesti ne voivat tyytyä vanhojen palvelujen ylläpitämiseen ja pitäytyä vain kirjastoalan sisäisten yhteistyömuotojen vaalimiseen. Ennakkoluulottomuus ja aktiivinen hakeutuminen uudenlaiseen yhteistyöhön kuitenkin palkitsee kirjastoja ja saattaa tuoda palvelujen kehittämiselle myös enemmän resursseja. Parhaimmillaan strategiatyö ja uudenlaisten palveluiden yhteisrakentaminen on kiinnostavaa, kannustavaa ja kirjastolaisia osallistavaa toimintaa. 


\section{Artikkeliin liittyviä lähteitä:}

United Nations, 20 I 5 . Transforming our world: the 2030 Agenda for Sustainable Development. New York, United Nations. https://sdgs.un.org/publications/transformingour-world-2030-agenda-sustainable-development-1798 I

IFLA, 2019. IFLA strategy 20I9-2024. Den Haag, IFLA.

https://www.ifla.org/files/assets/hq/gb/strategic-plan/ifla-strategy-2019-2024-en.pdf

OKM, 2017. Korkeakoulutus ja tutkimus 2030-luvulle: taustamuistio korkeakoulutuksen ja tutkimuksen 2030 visiotyölle. Helsinki, OKM.

https://minedu.fi/documents/I 4I0845/4I77242/visio2030-taustamuistio.pdf/b370esec66d3-44cb-acb9-7ac43 I 8c49c7/visio2030-taustamuistio.pdf

AMKIT-konsortio, 202 I. AMKIT-konsortion strategia 202 I-2025 (AMKIT-verkostopäivät). https://jamboard.google.com/d/rLdgZHhhWmn8CtdY9ogwVUPoagwtwPfBNcPYCicz OY6Q/edit?usp=sharing Luettu 22.2.202I.

Kansalliskirjasto, 202I. Kansalliskirjaston strategia 202 I-2030, http://urn.fi/URN:NBN:fi-fe20200402 I0186

Avoin tiede - Linjaukset ja aineistot. https://avointiede.fi/fi/linjaukset-ja-aineistot Korkeakoulujen yhteinen digivisio 2030. https://digivisio2030.fi/

Arene, 2020. Kestävä, vastuullinen ja hiilineutraali ammattikorkeakoulu Ammattikorkeakoulujen kestävän kehityksen ja vastuullisuuden ohjelma. http://www.arene.fi/wp-content/uploads/Raportit/2020/Kest\%C3\%A4v\% ${ }_{3} \mathrm{C}_{3} \% \mathrm{~A}_{4}{ }_{2}{ }_{2} \mathrm{O}$ vastuullinen\%20ja\%2ohiilineutraali\%20ammattikorkeakoulu.pdf?_t=I60614557 Dufva, M., 2020. Megatrendit 2020. Sitran selvityksiä I62. Helsinki, Sitra. https://www.sitra.fi/julkaisut/megatrendit-2020/

\section{Kirjoittajat:}

JARMO SAARTI

Mira Juppi

Savonian kirjasto

mira.juppi @savonia.fi

\section{Heli Kautonen}

SKs:n kirjasto

heli.kautonen@finlit.fi
Itä-Suomen yliopiston kirjasto

jarmo.saarti@uef.fi

Kimmo Tuominen

Helsingin yliopiston kirjasto

kimmo.k.tuominen@helsinki.fi

Hanna Lahtinen

Laurea-kirjasto

hanna.lahtinen@laurea.fi

\author{
Mita Willman \\ LUT-tiedekirjasto \\ miia.willman@lut.fi
}

LiIsa Savolainen

Kansalliskirjasto

liisa.savolainen@helsinki.fi 